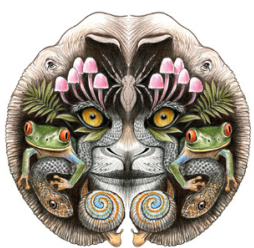

ISSN

Online 0974-7907

Print 0974-7893

OPEN ACCESS

\title{
ADDITIONAL RECORD OF BATASIO MERIANIENSIS (CHAUDHURI 1913), A CATFISH (TELEOSTEI: BAGRIDAE) IN UPPER BRAHMAPUTRA RIVER drainage in ARUnachal Pradesh, INDIA
}

\author{
Lakpa Tamang ${ }^{1} \&$ Bikramjit Sinha ${ }^{2}$
}

1,2 Zoological Survey of India, Arunachal Pradesh Regional Centre, Senki Valley, Itanagar, Arunachal Pradesh 791113,

${ }^{1}$ lakpatamang@rediffmail.com (corresponding author), ${ }^{2}$ sinhaj@gmail.com

Abstract: This paper communicates the extension of the distribution range of Batasio merianiensis in Sille River in the upper Brahmaputra drainage, East Siang District, Arunachal Pradesh. Detailed examinations of the specimens revealed existence of few morphological variations against those reported by Heok Hee $\mathrm{Ng}$ in 2009 on the following characteristics: by having a longer preanal (70.4-73.4 vs. $66.3-68.2 \%$ $\mathrm{SL})$; a longer prepectoral (25.1-29.3 vs. $21.4-25.7 \% \mathrm{SL}$ ); a longer adipose-fin base (22.0-27.6 vs. $16.9-22.2 \% \mathrm{SL}$ ); a shorter post-adipose distance (11.6-13.4 vs.13.4-15.5\% SL); a deeper body at anus (depth 18.3-20.8 vs.15.2-18.4\% SL) and broader head (width 17.6-20.0 vs.13.5-16.2 \% HL). Few additional characters of the fish are included along with brief information on its habitat. The LIPUM, the semitraditional method of fishing in the river is identified as a major threat to this species.

Keywords: Batasio merianiensis, habitat, possible threat, range extension, Sille River.

Bagrid catfishes of the genus Batasio Blyth, 1860 are species with small head, laterally compressed body that generally inhabit fast-flowing hill streams and large rivers throughout South and mainland Southeast Asia. The genus is characterized by the head with large sensory pores, a pair of prominent posterior processes present on the anterior part of the vomer, transversely elongated bar-like entopterygoid and the metapterygoid which are in close contact with the quadrate but free from the hyomandibular (Mo 1991). They are found in the sub-Himalayan region ranging from the Indus River drainage to the west, coastal rivers draining the eastern face of the Annam Cordilleras to the east, and the Perak River drainage to the south (Ng 2009). With the inclusion of one more species namely $B$. convexirostrum (Darshan et al. 2011), the total number of valid species now increased to 17 from the earlier 16 species reported by $\mathrm{Ng}$ (2008).

Batasio merianiensis, a poorly known species was originally described by Chaudhuri (1913) from a pond at Mariani Junction, Brahmaputra River drainage in Assam, northeastern India. The original description is exclusively based on the holotype and the taxonomic analysis exhibits old fashioned method of measurement without morphometric data, which is generally difficult to compare with other congeners. It was after a prolonged period of about nine decades, Ng (2009) could obtain fresh material from $16 \mathrm{~km}$ northwest of Kokrajhar, in the vicinity of Kumapara, Assam. He rediagnosed, redescribed and revalidated its species status. As information on the natural history of this species such as range of distribution, population size and trend, biology and potential impacts of anthropogenic threats remain poorly understood, Ng (2010) retained

DOI: http://dx.doi.org/10.11609/JoTT.03516.5738-43 | ZooBank: urn:Isid:zoobank.org:pub:1AD8732C-2CFD-4D32-8624-82236D18FF9B

Editor: W. Vishwanath, Manipur University, Imphal, India.

Date of publication: 26 May 2014 (online \& print)

Manuscript details: Ms \# 03516 | Received 05 February 2013 | Final received 06 May 2014 | Finally accepted 07 May 2014

Citation: Tamang, L. \& B. Sinha (2014). Additional record of Batasio merianiensis (Chaudhuri 1913), a catfish (Teleostei: Bagridae) in upper Brahmaputra River drainage in Arunachal Pradesh, India. Journal of Threatened Taxa 6(5): 5738-5743; http://dx.doi.org/10.11609/JoTT.03516.5738-43

Copyright: (c) Tamang \& Sinha 2014. Creative Commons Attribution 4.0 International License. JoTT allows unrestricted use of this article in any medium, reproduction and distribution by providing adequate credit to the authors and the source of publication.

Funding: Zoological Survey of India, Kolkata.

Competing Interest: The authors declare no competing interests.

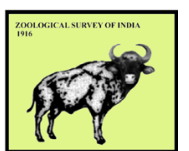

Acknowledgements: We extend our gratitude to Dr. K. Venkataraman, Director, Zoological Survey of India, Kolkata for facilities provided for this piece of research. Thanks to Dr. Dhrupad Choudhury, Programme Coordinator (ICIMOD, Kathmandu, Nepal) for his inspiration and encouragement to conduct ichthyological research in Arunachal Pradesh. 
it under the Data Deficient Category in the IUCN List of Threatened Species.

Until now five species of Batasio are recognized from the Brahmaputra River drainage, viz.: B. batasio, $B$. fasciolatus, B. spilurus, B. tengana and B. merianiensis (Ng 2006, 2009). Batasio merianiensis is easily distinguishable from the others except $B$. fasciolatus in having dark vertical bars on the head and body. This important character is also conspicuous in the present specimens. The important generic character of Batasio is the presence of prominent sensory pores on the head, description of which was missing in Ng (2009). We have added this here along with other additional characters.

Ichthyological survey in the upper Brahmaputra River basin revealed existence of undiscovered populations of Batasio in Sille River, which was later identified as $B$. merianiensis. There is no report of this poorly known species, its habitat or the anthropogenic threats it faces in this region, hence the present study serves to document this information.

\section{Materials and Methods}

Surveys were conducted during October 2012 in
Sille River, East Siang District, Arunachal Pradesh. Fish samples were collected from the heap of stones stored by local people. The collected specimens were preserved in $10 \%$ formalin and later transferred to $70 \%$ ethanol for preservation. The fish were identified following $\mathrm{Ng}$ (2009) and have been deposited in the Zoological Survey of India (ZSI), Arunachal Pradesh Regional Centre, Itanagar, Arunachal Pradesh. Measurements using digital calipers (Mitutoyo Corporation, Japan) to the nearest 0.1 $\mathrm{mm}$ and expressed as percentage of standard length (SL) or head length ( $\mathrm{HL})$. Counts and measurements were made on the left side of the specimens following ( $\mathrm{Ng}$ $\&$ Kottelat 2001). The number written in parentheses after a specific fin ray count indicates the number of specimens examined.

\section{Batasio merianiensis (Chaudhuri, 1913) (Images 1 \& 2)}

Macrones merianiensis Chaudhuri, 1913: 253, PI. 9 (Figs. 1, 1a-b) [type locality: pond at Mariani Junction, Assam, India, holotype, ZSI F7781/1].

Material examined: ZSI/V/APFS/P-602, 26-27.x.2012,

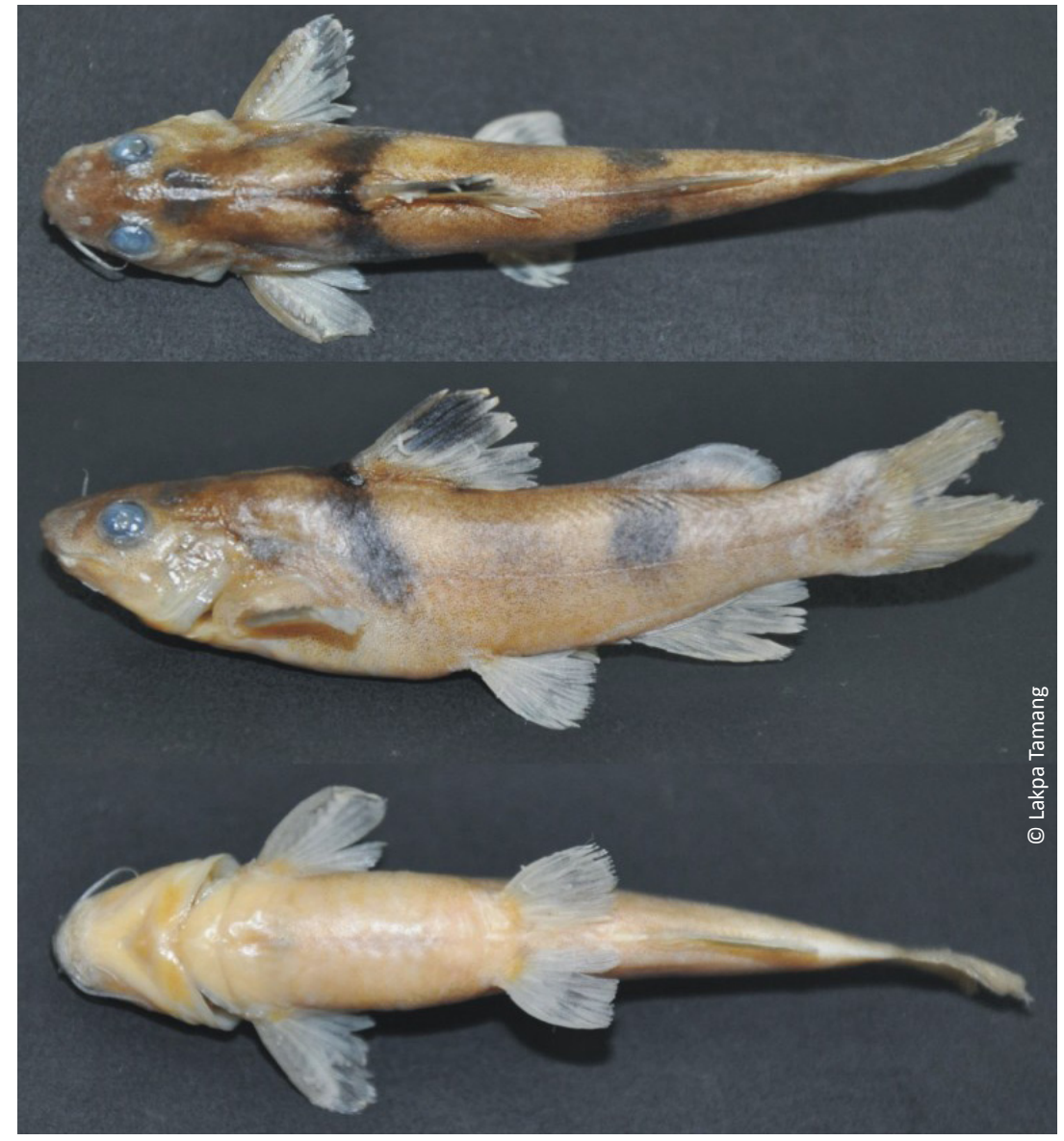

Image 1. Batasio merianiensis, ZSI/V/ APFS/P-602, 57.8mm SL; Male; dorsal, lateral and ventral views. 


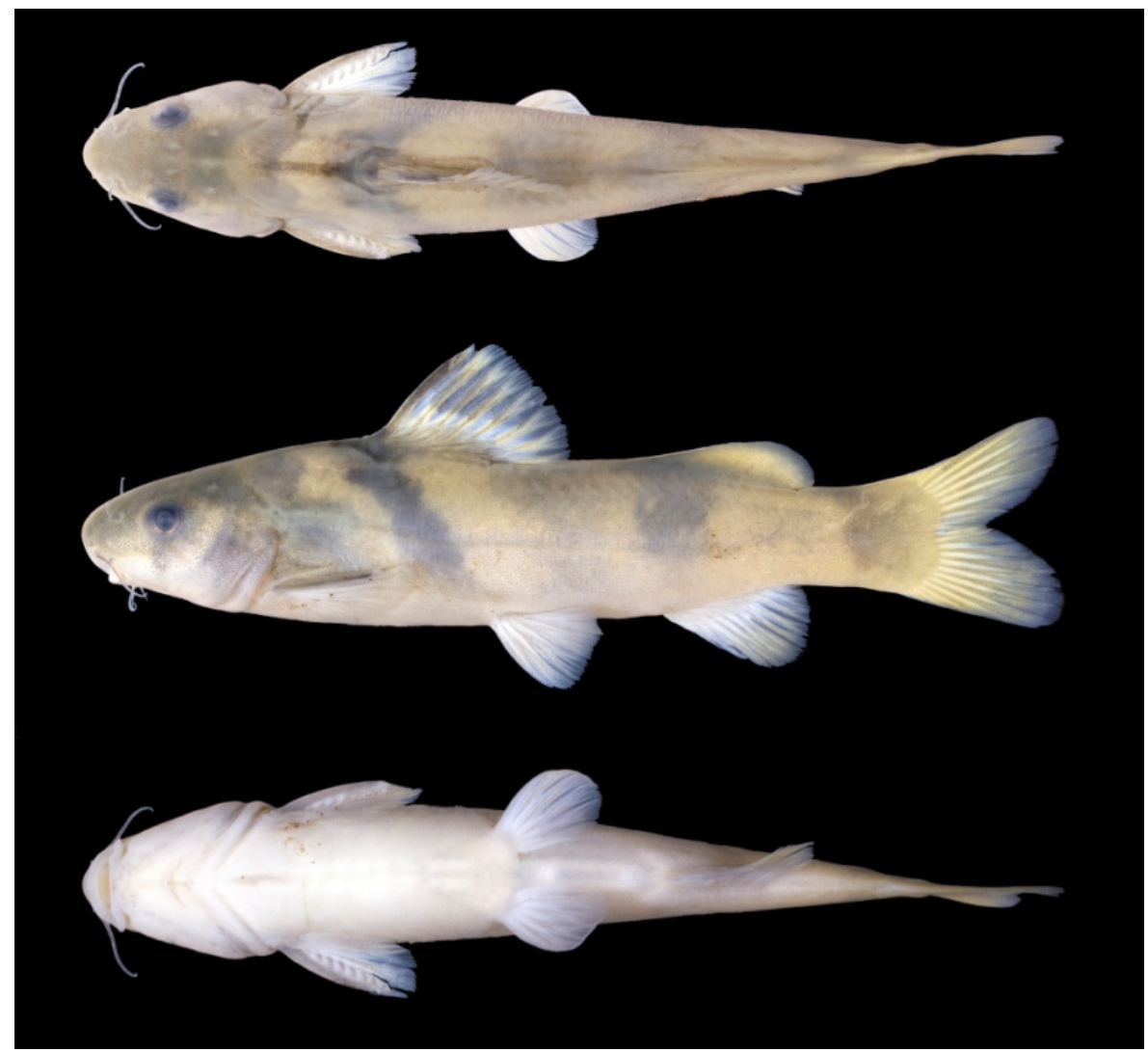

Image 2. Reproduced from $\mathrm{N}$ (2009): Batasio merianiensis, UMMZ 248780, 75.7mm SL; dorsal, lateral and ventral views six specimens, 43.4-57.8 mm SL, Sille River, about $1 \mathrm{~km}$ upstream from RCC bridge over Sille River, about $10 \mathrm{~km}$ from Ruksin, East Siang District, Arunachal Pradesh, India, 27052'38”N \& 95018'18”E; coll. Lakpa Tamang.

\section{Description}

Head is V-shaped when viewed dorsally and laterally (Image 1), it is longer than its width and depth, with 4-5 small sensory pores on dorsum region. Five distinct large sensory pores present immediately on the posterior region of lower lip (two pores situated in between the lower lip margin and the origin of mandibular barbel and one pore at mid line). Two rows of pores (four in each) along the side of mental region (Fig. 1). Maxillary barbels are reaching or slightly exceeding posterior orbital margin. Dorsal spine smooth, no serrations on its anterior or posterior margin. Pectoral fin with 8 (3); $7, i(2)$ and 7 (1) rays. Tip of adpressed pelvic fin reaching anterior margin of external genitalia, but not reaching anal-fin origin. Anal fin with iv,10 (1); iii,9 (1); iv,8 (2); iv, $7, i(1)$ and iii, 7 (1) rays. Caudal fin with i,7,10,i (4) and $i, 7,9, i(2)$ rays. A long slender genital papilla found in two specimens out of six, extending nearer to base of anal fin, which is a feature present in males. One male was found to be larger ( $57.8 \mathrm{~mm} \mathrm{SL}$ ) among all.

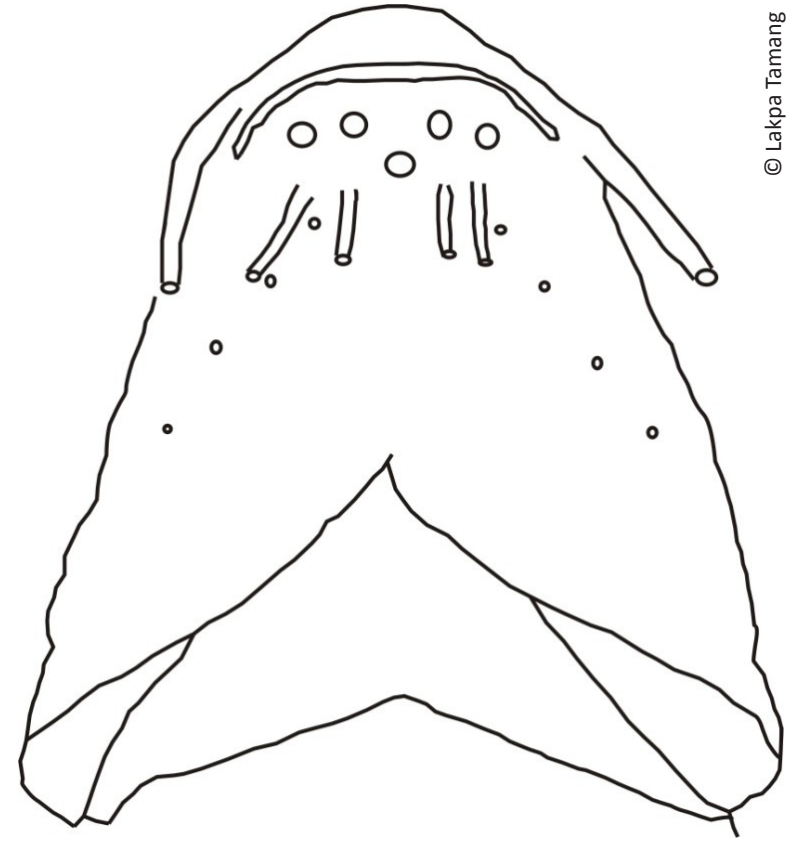

Figure 1. Schematic diagram of mental region of B. merianiensis showing the sensory pores.

Distance between pectoral-fin and pelvic-fin origin and between dorsal-fin and pelvic-fin origin is equal. Eye 
diameter almost equals internarial distance. Pectoral fin slightly shorter than dorsal fin. Dorsal-fin base equals to anal-fin base.

Coloration in preservative: Body and head faint brownish, darker at snout and occipital region. The Ventral surface is creamy. Eyes are grayish-white. Minute dark brown spots almost uniformly distributed all over the body and head.

Ecological notes: Batasio merianiensis were found to live in the bottom of clear shallow running water, the river comprised of pebbles, cobbles of variable colors and sand particles. The fish were found to dwell preferably inside the gaps under the heap of stones in stagnant water of depth about $(20-40 \mathrm{~cm})$ in the winter. River bank vegetation consists of grasses, bushes and trees. Following fishes were also captured along with B. merianiensis: Aborichthys elongatus, Acanthocobitis botia, Amblyceps mangois, Badis singenensis, Chanda nama, Garra annandalei, G. gotyla, Mastacembelus armatus, Pangio pangia, Pseudolaguvia viriosa, Pseudolaguvia sp., Schistura savona. Other species caught from adjacent area were Balitora brucei, Barilius barna, B. bendelisis, Botia rostrata, Crossocheilus latius, Neolissochilus hexagonolepis, Psilorhynchus balitora, Pethia ticto, and Tor tor.

Catching method: In the present study, we found that some local fishermen and farmers were fishing using semi-traditional fishing technique locally known as "LIPUM" in the study site. On inquiry, we learnt that this operation is carried out during the winter season (October-January) mostly. Medium size stones are deposited nearby river bank in a cylindrical pattern (ca. 15-20 inches high), which is generally left undisturbed for 3-4 weeks so as to allow fishes to enter inside. A modified mosquito net (cylindrical shape, top and bottom open) is used to cover the "LIPUM" completely and the stones are removed from inside the net and fishes are caught. In the study site, 10 LIPUMS or fishing spots were observed during our survey and found $90 \%$ catch frequency of $B$. merianiensis which indicates a normal population distribution of Batasio merianiensis in the study site.

\section{Distribution}

Known from the Brahmaputra River drainage in Arunachal Pradesh and Assam, northeastern India (Fig. 2). The Sille River is one of the tributaries of Siang River, which joins the Brahmaputra River in Assam.

\section{Discussion}

Among the other five species of Batasio reported from the Brahmaputra River drainage only $B$. merianiensis and $B$. fasciolatus have dark vertical bars on the head. The present specimens from upper Brahmaputra River

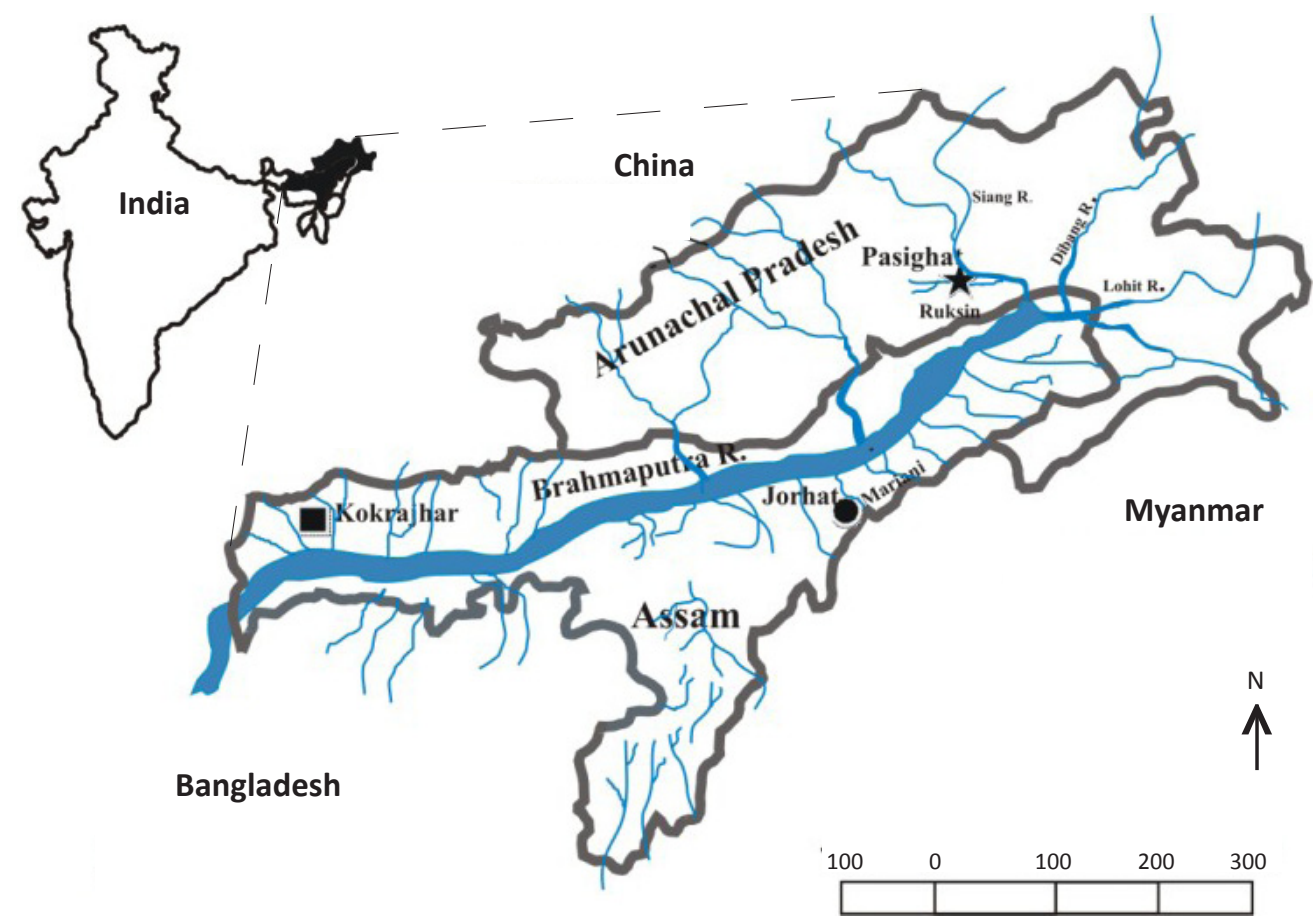

Figure 2. The distribution of Batasio merianiensis indicated by star (present collection), circle (Chaudhuri 1913) and square (Ng 2009). 
basin fully shares this important character however, can be easily distinguished from $B$. fasciolatus in having the adpressed dorsal fin not reaching (vs. overlapping) the anterior adipose-fin origin and in having larger eye (diameter 20.7-23.3 \% HL vs. 16.5-18.8). The dark brown subdistal ovoid patch on dorsal fin in the present specimens has close similarities with the original illustration of the holotype by Chaudhuri (1913: PI. 9, Fig. 1).

The present specimens shares most of the characters provided in the Table 1 which are closely related or overlapping particularly on the length of the predorsal, prepelvic, dorsal-fin base, dorsal-spine, anal-fin base, pectoral-fin, pectoral-spine, pelvic-fin, caudal-fin, head, snout, caudal peduncle, nasal-, maxillary-, inner-, and outer mandibular barbel with $B$. merianiensis. Other characters include caudal peduncle and head depth, dorsal to adipose- and interorbital distance, and eye diameter. In addition, the meristic feature in case of dorsal-, pelvic-fin rays and number of serrae on posterior margin of pectoral spine is exactly the same with negligible variations seen in pectoral-, anal- and caudal-fin rays (Table 2 ).

However, few morphological variations were

Table 1. Morphometric data of B. merianiensis.

\begin{tabular}{|c|c|c|c|c|c|}
\hline \multirow[b]{2}{*}{ Character } & \multicolumn{2}{|c|}{ Present specimens $(n=6)$} & \multicolumn{3}{|c|}{ Data from $\mathrm{Ng}(2009)(n=21)$} \\
\hline & Range & Mean $\pm S D$ & $\begin{array}{c}\text { Holotype } \\
\text { (ZSI F7781/1) }\end{array}$ & Range & Mean \pm SD \\
\hline Standard length & $43.4-57.8$ & & & & \\
\hline \multicolumn{6}{|l|}{$\% S L$} \\
\hline Predorsal length & $37.3-38.4$ & $37.9 \pm 0.5$ & 38.8 & $36.6-40.5$ & $37.7 \pm 1.31$ \\
\hline Preanal length & $70.4-73.4$ & $72.0 \pm 1.3$ & 67.9 & $66.3-68.2$ & $67.4 \pm 0.60$ \\
\hline Prepelvic length & $49.8-55.3$ & $53.1 \pm 2.4$ & 50.2 & $47.6-51.3$ & $49.9 \pm 1.13$ \\
\hline Prepectoral length & $25.1-29.3$ & $26.7 \pm 1.8$ & 22.5 & $21.4-25.7$ & $23.1 \pm 1.25$ \\
\hline Length of dorsal-fin base & $13.6-16.4$ & $15.4 \pm 1.1$ & 14.8 & $14.8-17.3$ & $16.2 \pm 0.78$ \\
\hline Dorsal-spine length & $12.8-16.8$ & $15.5 \pm 1.4$ & 16.6 & $13.5-16.7$ & $15.2 \pm 0.93$ \\
\hline Length of anal-fin base & $13.6-16.5$ & $15.2 \pm 1.0$ & 13.5 & $13.0-18.0$ & $15.2 \pm 1.29$ \\
\hline Pelvic-fin length & $14.6-19.7$ & $16.1 \pm 1.8$ & 16.9 & $12.3-16.9$ & $13.9 \pm 1.35$ \\
\hline Pectoral-fin length & $17.7-22.5$ & $20.1 \pm 1.7$ & 19.1 & $15.4-19.1$ & $17.2 \pm 1.10$ \\
\hline Pectoral-spine length & $14.8-18.6$ & $15.8 \pm 1.5$ & 16.3 & $12.2-16.3$ & $13.9 \pm 1.07$ \\
\hline Caudal-fin length & $20.2-25.7$ & $23.8 \pm 1.9$ & damaged & $21.2-25.0$ & $22.6 \pm 1.06$ \\
\hline Length of adipose-fin base & $22.0-27.6$ & $23.6 \pm 2.1$ & 22.2 & $16.9-22.2$ & $19.7 \pm 1.55$ \\
\hline Dorsal to adipose distance & $10.7-15.7$ & $13.8 \pm 1.7$ & 13.9 & $13.9-17.4$ & $15.9 \pm 1.00$ \\
\hline Post-adipose distance & $11.6-13.4$ & $12.4 \pm 0.9$ & 14.3 & $13.4-15.5$ & $14.3 \pm 0.69$ \\
\hline Caudal peduncle length & $12.2-17.2$ & $15.3 \pm 1.7$ & 17.7 & $16.4-19.5$ & $17.5 \pm 0.85$ \\
\hline Caudal peduncle depth & $10.7-11.9$ & $11.1 \pm 0.4$ & 10.5 & $9.7-11.9$ & $10.7 \pm 0.65$ \\
\hline Body depth at anus & $18.3-20.8$ & $19.5 \pm 0.8$ & 17.4 & $15.2-18.4$ & $16.8 \pm 1.05$ \\
\hline Head length & $25.1-27.8$ & $26.6 \pm 1.0$ & 24.0 & $24.0-26.5$ & $25.6 \pm 0.63$ \\
\hline Head width & $17.6-20.0$ & $19.0 \pm 1.0$ & 15.2 & $13.5-16.2$ & $15.2 \pm 0.77$ \\
\hline Head depth & $17.3-19.5$ & $18.2 \pm 0.8$ & 17.2 & $16.3-19.3$ & $17.3 \pm 0.96$ \\
\hline \multicolumn{6}{|l|}{$\% \mathrm{HL}$} \\
\hline Snout length & $37.2-42.2$ & $39.3 \pm 1.9$ & 39.2 & $36.7-40.9$ & $38.5 \pm 1.22$ \\
\hline Interorbital distance & $29.2-34.1$ & $32.1 \pm 1.7$ & 25.9 & $25.9-31.5$ & $29.1 \pm 1.58$ \\
\hline Eye diameter & $20.7-23.3$ & $21.9 \pm 1.1$ & 25.9 & $18.3-25.9$ & $21.5 \pm 1.52$ \\
\hline Nasal barbel length & $15.5-20.7$ & $18.0 \pm 1.7$ & 25.9 & $9.4-25.9$ & $16.2 \pm 4.12$ \\
\hline Maxillary barbel length & $24.4-48.7$ & $35.3 \pm 11.3$ & 52.5 & $36.8-54.5$ & $46.4 \pm 5.74$ \\
\hline Inner mandibular barbel length & $7.3-13.4$ & $11.4 \pm 2.2$ & 10.8 & $8.4-13.3$ & $11.4 \pm 1.68$ \\
\hline Outer mandibular barbel length & $16.7-22.1$ & $20.2 \pm 2.0$ & 14.6 & $14.3-23.2$ & $18.5 \pm 2.88$ \\
\hline
\end{tabular}


Table 2. Meristic data of B. merianiensis.

\begin{tabular}{|l|c|c|}
\hline & Present specimens (n-6) & Data from Ng (2009) (n=21) \\
\hline Dorsal fin rays & 7 & 7 \\
\hline pectoral fin rays & $7 ; 7, \mathrm{i} ; 8$ & $7 ; 8$ \\
\hline pelvic fin rays & $\mathrm{i}, 5$ & $\mathrm{i}, 5$ \\
\hline anal fin rays & $\mathrm{iii,7} ; \mathrm{iv}, 7 \mathrm{i} ; \mathrm{iv}, 8 ; \mathrm{iii}, 9 ; \mathrm{iv}, 10$ & $\mathrm{iv}, 8 ; \mathrm{v}, 8 ; \mathrm{iii}, 9 ; \mathrm{iv}, 9 ; \mathrm{iv}, 10$ \\
\hline caudal fin rays & $\mathrm{i}, 7,9, \mathrm{i} ; \mathrm{i}, 7,10, \mathrm{i}$ & $\mathrm{i}, 7 ; 8, \mathrm{i}$ \\
\hline Serrae on posterior margin of pectoral spine & $6-7$ & $6-7$ \\
\hline
\end{tabular}

observed on the following characters: by having a longer preanal (70.4-73.4 vs. 66.3-68.2\% SL); a longer prepectoral (25.1-29.3 vs. $21.4-25.7 \% \mathrm{SL}$ ); a longer adipose-fin base (22.0-27.6 vs. 16.9-22.2 \% SL); a shorter post-adipose distance (11.6-13.4 vs.13.4-15.5\% $\mathrm{SL}) ;$ a deeper body at anus (depth 18.3-20.8 vs.15.2$18.4 \% \mathrm{SL}$ ) and a broader head (width 17.6-20.0 vs.13.5$16.2 \% \mathrm{HL})$.

\section{Conclusion}

The extensive use of the semi-traditional fishing technique would obviously affect the population of Batasio merianiensis in the study site. Besides, mosquito nets are more hazardous as it holds up almost all sizes of fishes because of minute meshes. Thus such technique employed would obviously affect the natural growth of the population of the fish. As far as the preferred microhabitat of the fish is concerned, the situation would be worsened if non-conventional method of fishing such as the use of chemicals and electricity are employed as previously reported by Tamang \& Chaudhry (2012). Keeping in mind the moderate population size of the fish, its preferred micro habitats and excessive usage of the semi-traditional fishing method, there is an urgency to take necessary measures for the conservation of this poorly known species, continuous practicing of this fishing technique otherwise may eventually wipeout the species from the present study area.

\section{Reference}

Chaudhuri, B.L. (1913). Zoological results of the Abor Expedition, 1911-12. XVIII. Fish. Records of the Indian Museum 8(3): 243-257, Pls. 7-9.

Darshan, A., N. Anganthoibi \& W. Vishwanath (2011). Batasio convexirostrum, a new species of catfish (Teleostei: Bagridae) from Koladyne basin, India. Zootaxa 2901: 52-58.

Mo, T.P. (1991). Anatomy, Relationships and Systematics of the Bagridae (Teleostei: Siluroidei) With A Hypothesis of Siluroid Phylogeny. Theses Zoologicae 17, Koeltz, Koenigstein, 216pp.

Ng, H.H. (2006). The identity of Batasio tengana (Hamilton, 1822), with the description of two new species of Batasio from north-eastern India (Teleostei: Bagridae). Journal of Fish Biology 68(issue A): 101118; http://dx.doi.org/10.1111/j.0022-1112.2006.001019.x

Ng, H.H. (2008). Batasio procerus, a new species of catfish from northern Myanmar (Siluriformes: Bagridae). Ichthyological Exploration of Freshwaters 19(1): 1-6.

$\mathrm{Ng}$, H.H. (2009). Redescription of Batasio merianiensis, a catfish (Teleostei: Bagridae) from northeastern India. Journal of Threatened Taxa 1(5): 253-256; http://dx.doi.org/10.11609/JoTT.o2177.253-6

Ng, H.H. (2010). Batasio merianiensis. In: IUCN 2012. IUCN Red List of Threatened Species. Version 2012.2. <www.iucnredlist.org>. Downloaded on 27 January 2013.

Ng, H.H. \& M. Kottelat (2001). A review of the genus Batasio (Teleostei: Bagridae) in Indochina, with the description of $B$. tigrinus sp. n. from Thailand. Revue Suisse de Zoologie 108(3): 495-511.

Tamang, L. \& S. Chaudhry (2012). Range extension of Conta pectinata $\mathrm{Ng}, 2005$ (Teleostei: Sisoridae) in upper Brahmaputra River drainage in Arunachal Pradesh, India. Journal of Threatened Taxa 4(2): 24022405; http://dx.doi.org/10.11609/JoTT.o2933.2402-5 